\title{
MITOS DAN NILAI DALAM CERITA RAKYAT MASYARAKAT LAMPUNG
}

\author{
Oleh Tjetjep Rosmana \\ Balai Pelestarian Sejarah dan Nilai Tradisional Bandung \\ Jln. Cinambo No. 136 Ujungberung Bandung \\ Email: tjetjeprosmana@yahoo.co.id
}

Naskah diterima: 22 Maret 2010

Naskah disetujui: 22 Mei 2010

\section{Abstrak}

Untuk mengungkapkan nilai-nilai luhur, sesungguhnya terdapat di dalam cerita rakyat, antara lain nilai-nilai luhur yang menyangkut tentang ajaran moral, harga diri, jati diri, kerja keras, tegang rasa, dan sebagainya. Nilai-nilai tersebut sangat baik ditanamkan dalam kehidupan kita, terutama kepada anak-anak sebagai penerus bangsa. Dalam tulisan mitos dan nilai dalam cerita rakyat masyarakat Lampung ini menggunakan pendekatan deskritif analisis content untuk menjelaskan cerita rakyat yang dikumpulkan. Data yang dikumpulkan tersebut disusun dan dianalisis, terutama dari segi struktur cerita dan nilainya. Selain itu dipergunakan metode komparatif analisis untuk membedakan jenis cerita dengan harapan dapat menyimak nilai-nilai luhur tersebut sebagai sistem pengendalian sosial yang dapat mewujudkan kehidupan yang tenteram, bersatu, dan harmonis. Dari tulisan ini kiranya dapat digarisbawahi betapa pentingnya nilai-nilai luhur tersebut di dalam kehidupan kita, terutama untuk anak agar berbudi pekerti sebagai pembentuk karakter bangsa.

Kata kunci: folklor lisan, mitos dan nilai, masyarakat Lampung.

\section{Abstract}

Folklores are source for us to dig traditional values that live in society, such as the ones of moral, dignity, hard work, and others. This research is about myths and folklores of Lampung society. We/the author examined the structure and values that they convey to analyse meaning and content. The stories are compared one to another and a descriptive analitical approach was conducted to describe the result.

Keywords: oral folklore, myth and values, society of Lampung.

\section{A. PENDAHULUAN}

Dewasa ini, sangat jarang orang tua yang meneruskan kebiasaan menuturkan dongeng ataupun cerita rakyat kepada anak-anaknya Sesungguhnya banyak nilai-nilai luhur dalam cerita rakyat yang sangat baik ditanamkan bagi anak-anak, akan tetapi sekarang jarang dilakukan. Anak-anak cenderung mengalihkan waktu luangnya dengan menonton televisi yang banyak menampilkan unsur-unsur dari kebudayaan asing. Terlebih dengan semakin sibuknya para orang tua sehingga tidak mempunyai kesempatan untuk mendampingi putra-putrinya, maka ketergantungan anak terhadap hiburan televisi semakin tinggi. Selanjutnya, anak-anak pun mempunyai referensi baru mengenai tokoh idolanya melalui film kartun. 
Mereka banyak memfigurkan tokohtokoh herois bangsa lain. Padahal banyak tokoh-tokoh herois bangsa, yang dapat dibanggakan dan dijadikan figur bagi generasi penerus, yang antara lain dapat diperoleh melalui cerita rakyat.

Menyimak saratnya nilai yang terkandung dalam cerita rakyat, maka dapat dikatakan bahwa cerita rakyat dapat dipakai sebagai sarana pembinaan yang bersifat preventif atau pencegahan dalam arti melestarikan dan menanamkan nilai atau normanorma yang dapat dipakai sebagai pedoman atau aturan untuk berbuat bagi individu dalam kehidupan keluarga, dan umumnya kehidupan masyarakat. Dengan kata lain cerita rakyat (mite, legenda, ataupun dongeng) dapat dipakai sebagai sistem pengendalian sosial yang dapat mewujudkan kehidupan yang tenteram, berkesatuan, dan harmonis.

Upaya menggali dan memperkenalkan cerita rakyat, berarti sama halnya dengan mencari dan memperkenalkan identitas daerah pemiliknya. Oleh karena itu cerita rakyat di setiap daerah perlu diperkenalkan kepada masyarakat secara turun temurun, maksudnya agar masyarakat terutama generasi penerusnya mengetahui identitas daerahnya.

Selain untuk mengenal identitas daerah serta memperkaya kebudayaan daerah khususnya, dan umumnya untuk memperkaya kebudayaan Indonesia, cerita rakyat juga berfungsi sebagai alat untuk mewariskan adat istiadat dan kebiasaan, serta kepercayaan; untuk menyampaikan pendidikan; dan untuk menyampaikan asal-usul kejadian atau hal-hal yang mengandung berita maupun sejarah. Melalui cerita rakyat, generasi penerus diharapkan mengenal asal usul nenek moyangnya serta mengetahui dan menghargai jasa orang jaman dahulu yang telah berbuat sesuatu yang bermanfaat bagi masyarakat, daerah dan keturunannya.

Pokok permasalahan adalah penuturan cerita rakyat secara tradisional makin jarang dilakukan. Hal itu mengakibatkan banyaknya penutur yang lupa akan cerita-cerita rakyat yang pernah didengarnya. Kebiasaan orang tua mewariskan cerita-cerita rakyat pada anak-anaknya dengan cara mendongeng sebelum tidur makin terdesak oleh adanya hiburan yang mempunyai konotasi "modern" seperti televisi, radio, cerita komik, kaset, $\mathrm{vcd} / \mathrm{dvd}$, dan lain sebagainya.

Apabila tidak sedini mungkin cerita rakyat itu diperkenalkan kembali kepada generasi muda, tentu tidaklah mengherankan kalau cerita-cerita tersebut makin lama makin tidak dikenali. Apalagi bila orang tua tidak menuturkannya lagi, tentu mereka mulai lupa akan cerita-cerita rakyat itu. Apabila hal itu terjadi dikhawatirkan cerita-cerita itu akan punah dan menyebabkan pemiskinan mental mengingat fungsi dan peran cerita rakyat yang mampu mengarahkan perilaku seseorang agar sesuai dengan nilai dan norma yang berlaku dalam masyarakatnya.

Salah satu hal yang menyebabkan begitu pentingnya cerita rakyat dalam upaya mewujudkan kehidupan yang tenteram, berkesatuan, dan harmonis adalah saratnya cerita rakyat dengan nilai-nilai luhur budaya bangsa yang bisa dijadikan pedoman 
atau aturan untuk bersikap dan berperilaku. Mengingat hal tersebut, pengkajian beberapa cerita rakyat di Lampung ini berusaha mencari jawaban atas pertanyaan :

1. Nilai-nilai apakah yang terkandung dalam cerita rakyat masyarakat Lampung?

2. Bagaimanakah relevansi nilai-nilai yang terkandung dalam cerita rakyat tersebut dengan kehidupan bermasyarakat dewasa ini ?

Pengkajian ini bertujuan untuk mengungkapkan nilai-nilai luhur yang terkandung di dalam cerita rakyat yang tumbuh dan berkembang di Lampung dan mengetahui relevansi nilai-nilai luhur tersebut terhadap kehidupan masyarakat dewasa ini. Selain itu, juga melalui pengkajian ini diharapkan dapat menyisihkan dan menuai kembali nilai-nilai luhur tersebut untuk dijadikan gagasan dan keyakinan yang sifatnya informatif sesuai dengan perkembangan jaman. Nilai-nilai luhur tersebut diharapkan tidak hanya dipandang sebagai nilai tradisional belaka, tetapi dapat disisipkan sebagai rangsangan pemacu ke arah pembaharuan yang kreatif.

Materi pengkajian dibatasi pada beberapa cerita rakyat yang dikenal oleh orang Lampung, khususnya cerita rakyat yang terdapat di Lampung Timur serta yang mencerminkan identitas kebudayaannya. Selain itu, yang dianggap dapat mewakili masyarakat Lampung Timur secara keseluruhan, serta terdapat unsur mitosnya, nilai-nilai budaya yang terkandung di dalamnya, serta yang ada relevansi dengan nilai-nilai budaya dalam dengan kehidupan di masa sekarang maupun masa yang akan datang.
Fokus yang akan dikaji adalah merujuk pada kajian mitos dan nilai dalam cerita rakyat yang tumbuh, beredar, dan berkembang di masyarakat pendukungnya.

Mitos menurut Kamus Besar Bahasa Indonesia (1990 : 588) artinya cerita suatu bangsa tentang dewa atau pahlawan zaman dahulu, yang mengandung penafsiran tentang asal usul semesta alam, manusia, dan bangsa itu sendiri yang mengandung arti mendalam yang diungkapkan dengan cara gaib. Sedangkan Panuti Sudjiman (1984 : 50) mengartikan kata "mitos" dalam dua pengertian, yaitu : 1) cerita rakyat legendaris atau tradisional, biasanya bertokoh makhluk luar biasa dan mengisahkan peristiwaperistiwa yang tidak dijelaskan secara rasional, seperti cerita terjadinya sesuatu; 2) kepercayaan atau keyakinan yang tidak terbukti tetapi yang diterima mentah-mentah.

Telah diuraikan di muka, fokus telaah akan merujuk pada kajian mitos dan nilai dalam cerita rakyat yang tumbuh, beredar, dan berkembang di masyarakat Lampung. Adapun pengertian mitos menurut Kamus Besar Bahasa Indonesia (1990:588) artinya cerita suatu bangsa tentang dewa atau pahlawan zaman dahulu, yang mengandung penafsiran tentang asal usul semesta alam, manusia, dan bangsa itu sendiri yang mengandung arti mendalam yang diungkapkan dengan cara gaib. Sedangkan Panuti Sudjiman (1984 : 50) mengartikan kata "mitos" dalam dua pengertian, yaitu : 1) cerita rakyat legendaris atau tradisional, biasanya bertokoh makhluk luar biasa dan mengisahkan peristiwaperistiwa yang tidak dijelaskan secara rasional, seperti cerita terjadinya 
sesuatu; 2) kepercayaan atau keyakinan yang tidak terbukti tetapi yang diterima mentah-mentah.

Bicara mengenai Mitos, tidak bisa dilepaskan dari pengertian mitologis dan legendaris. Muchtar dkk. (1980/1981 : 2 - 3) mengartikan istilah mitologis sebagai sifat cerita yang berupa mite, yaitu cerita yang dikenal di kalangan masyarakat di daerah asal atau persebaran cerita tersebut dengan tokoh-tokoh yang dianggap keramat. Kisah tokoh yang terkandung dalam mite itu dalam anggapan masyarakat pendukungnya terjadi pada masa purba dan dalam lingkungan alam lain, sedangkan pengaruh daya kekeramatannya masih ada dalam kehidupan masyarakat. Adapun yang dimaksud dengan istilah legendaris ialah sifat cerita yang berupa legende, yaitu cerita yang dikenal di kalangan masyarakat di daerah asal atau tempat persebaran cerita tersebut dengan tokoh-tokoh yang dianggap pernah ada, tetapi kisahnya tinggal menjadi dongeng saja dan tidak mengandung kekeramatan. Tokoh-tokoh legendaris tergolong sebagai manusia biasa dengan sifat-sifat dan kekuatan luar biasa, seperti kekuatan supranatural atau kekuatan makhluk gaib yang dikuasainya. Kisahnya dianggap terjadi pada masa lampau, tetapi tidak setua masa kejadian yang digambarkan dalam mite.

Meskipun demikian, tidaklah selalu mudah membedakan antara legende dengan mite, seperti juga dikatakan oleh Ralp L. Beals dan Herry Hoijer (1956: 565 - 566), bahkan Fairchild (1962: 200) rupanya menyamakan saja kedua pengertian itu, ia berkata bahwa "mythical berarti relating to a belief, person or object of unproven existences; derived from myth or legend". Melihat bahwa perbedaan antara mitologis dengan legendaris tidak selalu jelas, tidaklah mengherankan kalau orang kadangkadang tidak sependapat apakah seorang tokoh itu termasuk legendaris.

Dalam batasan yang diberikan pertama tadi terdapat juga hal-hal mitologis yang tidak selalu sesuai dengan kenyataan, misalnya bahwa tokoh legendaris tidak dikeramatkan dan bahwa kisahnya dianggap tidak sesuai dengan kejadian yang digambarkan dalam mite. Dalam mengumpulkan cerita-cerita rakyat dapat saja ditemukan tokoh mitologis yang kejadian ceritanya dianggap tidak setua tokoh legendaris. Demikian pula, tokoh yang dikeramatkan pun dapat saja dianggap manusia biasa dengan sifat-sifat dan kekuatan luar biasa seperti tokoh yang tidak dikeramatkan.

Karena perbedaan yang tidak selalu jelas itu, mungkin saja para pembaca cerita rakyat akan mempunyai perbedaan pendapat pula tentang apakah seorang tokoh yang diceritakan itu termasuk legendaris atau mitologis.

Adapun pengertian nilai dalam sebuah karya sastra lama, baik lisan maupun tulisan merupakan unsur esensial dari karya sastra itu secara keseluruhan. Oleh karena itu, mengungkapkan nilai-nilai yang terdapat dalam cerita rakyat, secara tidak langsung akan memberikan pengertian latar belakang sosial budaya masyarakat pendukungnya di mana cerita itu tumbuh dan berkembang serta diterima dan dipedomani oleh masyarakat pendukungnya. 
Cerita rakyat sarat akan nilainilai budaya yang dapat mengekspresikan situasi pada jamannya. Sebagaimana dikemukakan oleh Supardi Djoko Darmono, bahwa sastra mencerminkan moral, yakni ukuran perilaku yang oleh anggota masyarakat diterima sebagai cara yang benar untuk bertindak dan menyimpulkan sesuatu, sastra juga mencerminkan nilai-nilai yang secara sadar diformulasikan dan diusahakan oleh warganya dalam masyarakat (Ahmad Yunus dkk., 1990 : 104).

Pengertian nilai yang dimaksud adalah kadar isi yang memiliki sifatsifat atau hal-hal yang penting atau berguna bagi kemanusiaan (Purwadarminta, 1985:677). Sebenarnya pengertian nilai dan norma selalu berkaitan, walaupun demikian keduanya dapat dibedakan. Nilai dimaksudkan sesuatu ukuran, patokanpatokan, anggapan-anggapan, keyakinan-keyakinan yang dianut oleh banyak warga dalam suatu masyarakat tertentu mengenai apa yang benar, pantas, luhur dan baik untuk dikerjakan, dilaksanakan atau diperhatikan. Sedangkan morma lebih merupakan aturan-aturan dengan sanksi-sanksi tertentu dengan tujuan untuk mendorong bahkan menekankan seseorang atau kelompok orang secara keseluruhan untuk mencapai nilai sosial.

Nilai-nilai dalam cerita rakyat dapat diklasifikasikan menjadi beberapa bentuk nilai, antara lain nilai keagamaan dan keyakinan (religius), nilai budaya, dan nilai sosial.

\section{Nilai Religius}

Karya sastra lama, lisan maupun tulisan disesuaikan dengan kebutuhan masyarakat atau latar belakang kehidupan pada jamannya. Kehidupan beragama pada jaman dulu memegang peranan penting sebagai obyek dalam cerita rakyat, misalnya cerita tentang penyebaran agama Islam di Indonesia. Banyak di antara cerita di daerah tersebut yang pada umumnya merupakan sarana penyampaian nilainilai keagamaan (Islam).

Secara definitif, Sir James G. Frazer merumuskan pengertian istilah agama atau religi : "Religi adalah segala sistem tingkah laku manusia untuk mencapai suatu maksud dengan cara menyandarkan diri kepada kemauan dan kekuasaan makhlukmakhluk halus seperti roh-roh, dewadewa dan sebagainya yang menempati alam (dalam Koentjaraningrat, 1987 : 54). Selain dari komponen tingkah laku tersebut, secara teoritis setiap sistem religi mencakup pula cara penyembahan dan obyek-obyek penyembahan yang dianggap memiliki kemauan dan kekuasaan.

Religi adalah rangkaian keyakinan mengenai makhluk supranatural, aktivitas upacara, serta sarana-sarana yang berfungsi melaksanakan komunikasi antara manusia dan makhluk supranatural. Makhluk supranatural memiliki kekuatan, dan keberadaan serta caracara untuk berkomunikasi dengannya disampaikan melalui simbol-simbol tertentu (Fausiah dalam Sawerigading, 1998/1999 : 79).

Sehubungan dengan pembicaraan mengenai karya sastra dan agama, Y.B Mangunwijaya lebih cenderung memakai istilah religius dan religiusitas, dari pada agama atau religi. Selanjutnya ia mengatakan, bahwa pada mulanya segala sastra 
adalah religius, sedangkan kalau agama lebih merujuk kepada kelembagaan kebaktian kepada Tuhan, atau kepada 'dunia atas' dalam aspek yang resmi. Akan tetapi religiusitas melihat aspeknya yang dalam 'lubuk hati', riak getaran hati nurani pribadi, dan sikap personal yang sedikit banyak misteri bagi orang lain (Mangunwijaya, 1982 : 11).

Menurut Adre Harjana, sastra keagamaan teresbut berindividualitas, bila dipandang dari segi keagamaan formal tertentu, dan sekaligus tidak berindiviualitas alias universal (1981: 88)

\section{Nilai Budaya}

Telah disebutkan sebelumnya bahwa di dalam karya sastra lisan maupun tulisan terkandung nilai-nilai yang secara sadar diformulasikan dan diusahakan oleh masyarakat pendukungnya. Dalam pernyataan ini telah tersimpul pengertian nilai budaya, sebagaimana yang disimpulkan bahwa nilai budaya adalah aspek ideal yang terwujud sebagai konsepsi-konsepsi abstrak yang hidup dalam pikiran sebagian besar dari warga sesuatu masyarakat mengenai apa yang harus dianggap penting dan berharga dalam hidup manusia ( Koentjaraningrat, dalam Ahmad Yunus dkk., 1990 : 111).

Koentjaraningrat mengatakan bahwa yang dimaksud dengan nilai budaya merupakan inti dari keseluruhan kebudayaan. Sedangkan sistem nilai budaya adalah bagian dari sistem budaya dan merupakan tingkat yang paling abstrak dari adat. Sistem nilai budaya ini terdiri dari konsepsikonsepsi yang hidup dalam alam pikiran sebagian besar warga masyarakat mengenai hal-hal yang harus mereka anggap amat bernilai dalam hidup manusia. (1982: 25) Sistem nilai budaya biasanya berfungsi sebagai pedoman tertinggi atau menjiwai semua pedoman, yang mengatur tingkah laku warga yang bersangkutan.

Oleh karena sistem nilai budaya berfungsi sebagai pedoman tertinggi bagi warga masyarakat, maka pandangan hidup seseorang juga diwarnai oleh apa yang dianggap ideal dalam pola berpikir masyarakat tersebut.

Dalam Kamus Besar Bahasa Indonesia, nilai artinya sifat-sifat atau hal-hal yang penting atau berguna bagi kemanusiaan (1995 : 690). Sedangkan budaya berasal dari kata sanskerta "buddhi" berarti "budi" atau "akal" (Koentjaraningrat, 1982 : 9). Dalam KBBI, kata "budaya" diartikan sebagai pikiran, akal budi, adat istiadat, atau sesuatu mengenai kebudayaan yang sudah berkembang (beradab, maju).

Definisi nilai budaya menurut Kamus Besar Bahasa Indonesia (1995: 679) adalah konsep abstrak mengenai masalah yang sangat penting dan bernilai dalam kehidupan manusia. Oleh karena itu, apabila menelaah isi dari cerita-cerita rakyat akan diperoleh informasi bahwa sudah sejak lama generasi pendahulu bangsa Indonesia ini memiliki penilaian mengenai citra yang diharapkan oleh masyarakat pada waktu itu.

Pigeaud mengatakan bahwa karya sastra klasik mengandung isi yang relatif luas meliputi bidang agama dan etika, sejarah dan mitologi, sastra, seni, hukum, ilmu masyarakat, cerita 
rakyat, adat istiadat dan serba-serbi (Pigeaud, 1967 : 45).

Dalam wujud yang lebih konkrit nilai budaya ini berupa norma-norma, aturan-aturan dan hukum yang menjadi pedoman bagi manusia dalam bertindak dan berperilaku. Selanjutnya, Koentjaraningrat mengkatagorikan kebudayaan ke dalam tiga aspek, yaitu aspek tata kelakuan yang merupakan perangkat ide dan gagasan manusia dan berisikan nilai budaya, aspek kelakuan manusia yang merupakan kesatuan gejala yang dapat diamati, dan aspek fisik yang merupakan hasil-hasil dari kelakuan manusia.

Walaupun karya sastra lama merupakan hasil ciptaan si penulis pada masa yang lampau, namum apa yang disampaikan masih bermanfaat bagi generasi penerusnya. Pada dasarnya seorang pengarang dalam menciptakan karyanya tidak semata-mata mencipta. Tetapi baik secara sadar ataupun tidak juga menuju pada suatu arah tertentu yang menjadi maksudnya. Suatu maksud itulah yang disebut makna ajaran atau amanat Bila ditelaah dalam cerita-cerita rakyat terdapat nilai-nilai ajaran yang sangat berguna bagi masyarakat, seperti nilai religi, kegotongroyongan, nilai tentang kearifan, dan masih banyak lagi.

\section{Nilai Sosial}

Nilai sosial erat kaitannya dengan nilai budaya maupun nilai religius. Ketiga nilai ini satu dengan yang lainnya tidak dapat dipisahpisahkan, sebab merupakan satu kesatuan yang utuh dalam kebutuhan kehidupan manusia. Dalam tingkat abstraksinya nilai sosial akan tampak lebh nyata dibanding nilai budaya. Kalau nilai budaya merupakan gagasan-gagasan dan pola ideal masyarakat tentang segala sesuatu yang dipandang baik dan berguna, maka pada nilai-nilai sosial gagasan itu telah dituangkan dalam bentuk normanorma, aturan-aturan, dan hukum. Nilai sosial inilah yang menjadi pedoman langsung bagi setiap tingkah laku manusia sebagai anggota suatu masyarakat, yang di dalamnya memuat sanksi-sanksi bagi siapa saja yang melanggarnya.

Metode yang dipergunakan dalam penelitian adalah deskriptif. Di samping itu juga digunakan metode komparatif untuk mengklasifikasi jenis cerita rakyat (mite, legenda atau dongeng). Dengan demikian, diupayakan tidak terjadi kesalahpahaman dalam menentukan sifat dan isi dalam cerita rakyat tersebut.

Langkah-langkah yang ditempuh dalam penelitian meliputi persiapan, pengumpulan data, pengolahan dan analisis data.

Tahap persiapan merupakan tahap awal dari kegiatan penelitian. Tahap ini merupakan tahap perencanaan seperti membuat instrumen penelitian (peralatan penelitian dan pedoman pengumpulan data).

Tahap pengumpulan data meliputi studi pustaka dalam upaya untuk menghasilkan data sekunder dan bahan pembanding dalam pengklasifikasian serta pengkajian, juga sebagai pedoman dalam pelaksanaan penelitian terutama dalam teori-teori yang berkenaan dengan cerita rakyat. Studi pustaka juga dilakukan untuk mencari cerita rakyat yang telah dibukukan atau didokumentasikan.

Penggunaan wawancara dalam penelitian ini merupakan hal yang sangat penting karena berfungsi sebagai penunjang untuk mendapatkan data yang valid. Informan dipilih ber- 
dasarkan kemampuannya dalam menuturkan cerita, serta mengetahui dan memahami makna atau artinya yang terkandung di dalam cerita rakyat. Dengan langkah itu, laporan hasil penelitian diharapkan memadai dan dapat dipertanggungjawabkan.

Tahap pengolahan data yang dimaksud disini adalah penginventarisasian dan pengklasifikasian cerita rakyat yang berhasil dikumpulkan. Setelah data diklasifikasikan, tahap berikutnya adalah menganalisa data. Ini adalah tahap yang penting dan menentukan. Pada tahap inilah data dikerjakan dan dimanfaatkan sedemikian rupa sampai berhasil menyimpulkan kebenarankebenaran yang dapat dipakai untuk menjawab persoalan-persoalan yang diajukan dalam penelitian.

Tujuan analisa data adalah menyederhanakan data ke dalam bentuk yang lebih mudah dibaca dan diinterprestasikan. Kegiatan analisa data ini dilakukan dengan cara mengkaji unsur mitos yang terkandung dalam cerita rakyat, mengkaji nilai budaya yang terkandung di dalamnya, juga mengkaji relevansi dari nilai budaya yang terkandung dalam karya tersebut pada kehidupan di masa sekarang maupun di masa yang akan datang.

Di dalam tahap pengolahan data ini dilakukan juga integrasi data serta informasi primer dengan tambahan yang sekunder. Dilanjutkan dengan mengorganisir data sesuai dengan kerangka penulisan ini.

\section{B. HASIL DAN BAHASAN}

Berikut ini akan disajikan mitos dan nilai dalam beberapa cerita rakyat yang beredar di Lampung, khususnya di masyarakat Lampung Timur. Bila di kaji dari segi mitos nilai, cerita rakyat tersebut memiliki nilai-nilai sebagai berikut:

\section{Nilai religius}

Nilai religius dapat terungkap dalam cerita ini, ketika Raden Sukat hatinya merasa sedih dan hampa lantaran lamarannya ditolak oleh orang tua Raden Gayung. Ia tidak dapat berbuat apa-apa, tapi menyerahkan segalanya kepada Allah SWT yang telah menciptakan semuanya. Dialah yang menentukan segalanya. Sebagai manusia hanya wajib berusaha. Ia yakin masalah cinta kasih (jodoh), hanya Allah SWT yang menentukan. Demikian pula dirinya dengan Raden Gayung, bila Allah SWT menghendakinya, tentu Raden Sukat akan bersatu dalam membina rumah tangga dengan Raden Gayung. Oleh karena itu, Raden Sukat bertekad bulat pergi mengembara untuk guru guna memperdalam ilmu ajaran Islam.

Kejadian pahit yang menimpa keluaraga Raden Sukat menjadi pelajaran dan pengalaman yang bermanfaat, khusus bagi Raden Sukat. Dengan ditolak lamarannya, tidak berarti Raden Sukat harus putus asa dan patah semangat, justru dia sebaliknya. Lebih ulet dalam bekerja mencari ilmu agama, terus berjuang menegakan kebajikan, dan lebih meningkatkan ketaqwaan kepada Allah SWT. Sejak itu pula dia, mampu menimba ilmu-ilmu baik yang berhubungan dengan ilmu kesehatan, ilmu bela diri, maupun ilmu ajaran agama. 
Bagi orang tua Raden Gayung, menyadari bahwa sebenarnya Allah SWT tidak membedakan manusia berdasarkan status garis keturunan (adat) maupun kaya dan miskin. Namun Allah SWT memandang manusia itu sama derajatnya, dan yang membedakan hanya ketakwaannya.

Nilai religius yang terungkap dalam cerita ini dikisahkan bahwa Akhmad seorang pemuda yang soleh, ia patuh mengerjakan perintah agama (Islam). Setiap hari, setelah mengerjakan sholat yang lima waktu ia selalu mengerjakan berbagai macam sholat, dan di malam hari berzikir mengagungkan nama Allah SWT. Namun, segala kehilapan tak luput hinggap pada dirinya. Pada suatu saat ia enemukan buah apel yang hanyut di sungai, ia memungutnya tanpa terlebih dahulu menyebut Asma Allah. Tidak pula mengucapkan Alhamdulillah Wasyukurillah, malah langsung memakannya tanpa mengucapkan Bissmillahirohmanirrohim. Namun, sebagai seorang yang beriman, ia mengaku segala kehilapan serta menyadari kesalahan, ia pun berjanji akan meminta maaf kepada pemilik buah apel tersebut. Ia berani menebus kesalahan walaupun si pemilik buah apel memberi sanksi memperbudaknya selama setahun. Bahkan ia bersedia mengawini anak gadis si pemilik buah apel yang katanya si gadis tersebut mata buta, pendengaran tuli, dan kakinya berjalan pincang. Namun keteguhan hati untuk menebus dosanya, tidak akan pudar, luntur atau pun berubah ia tetap berpendirian menjalaninya dengan hati ikhlas dan tawakal. Akhmad mendapat cobaan dari Allah SWT yang diwujudkan melalui Pak tua pemilik buah apel.
Sebagai orang yang bertaqwa ia menepati janji untuk menebus kesalahan kepada Allah SWT. Ia bersedia mengawini anak gadis Pak Tua walau anak gadis itu buta, tuli dan pincang. Atas ketulusan dan keiklsan Akhmad, Allah SWT memberikan berkah, dan sesuatu yang terbaik demi kebahagiannya.Atas kebesaran dan kehendak Allah SWT akhirnya Akhmad menikah dengan seorang gadis anaknya Pak Tua. Awalnya ia tidak percaya bahwa gadis yang akan dinikahinya seorang yang cacat jasmani, seperti yang dikatakan oleh Pak Tua, namun lain yang dimaksud Pak Tua. Setelah menikah mereka tinggal dirumah Pak Tua, dan dikaruniai seorang anak laki-laki yang diberi nama Abdullah. Dua tahun kemudian Akhmad meninggal dunia. Kini Abdullah hidup bersama ibu dan kakeknya. Setelah dewasa Abdullah memiliki sifat dan prilaku sama seperti ayahnya dan menjadi anak yang saleh.

Cerita Betung Bengawan ini mengandung nilai religius. Maksudnya memiliki nilai kepercayaan yang melukiskan kemujijatan seorang tokoh yang merupakan suatu keajaiban mengenai kejadian atau peristiwa yang menyimpang dari hukum alam. Unsur kemujijatan yang dapat dijumpai dalam cerita ini, yaitu beberapa keajaiban yang dimiliki oleh anak raja yang ketujuh, yakni bernama Pangiran Sangun Ratu Kabuyutan. Keajaiban pertama, ia tidak selayaknya manusia biasa yang lahir melalui rahim seorang ibu, tapi ia dilahirkan dari belahan ruas bambu besar, dan sejak kelahirannya ia pun sudah dapat berjalan dan bicara. Keajaiban yang kedua terjadi ketika ia dicari oleh penduduk kampung, karena disangka sebagai penyebab robohnya 
balai desa. Namun ketika ia berpapasan, mereka tidak dapat melihatnya. Pangiran Sangun, memiliki kelebihan dapat merubah wajah istrinya melebihi kecantikan sewaktu ia masih gadis. Peristiwa ini tentu sangat mengejutkan mertuanya, tidak mengira Pangiran Sangun memiliki keajaiban yang luar biasa. Namun, peristiwa atau kejadian keajaiban di atas semua atas kebesaran dan kekuasaan Allah SWT, yang diwujudkan melalui Pangiran Sangun. Karena, bila sesuatu itu atas kehendakNya, semua pun tidak ada yang tidak mungkin terjadi. Tokoh Pangiran Sangun, dalam cerita ini dianggap sebagai tokoh orang suci, yang memiliki berkah dan kelebihan secara alami, bila dibandingkan dengan tokoh yang lainnya.

\section{Nilai Budaya}

Nilai budaya dapat terungkap ketika orang tua Raden Gayung walaupun termasuk seorang bangsawan yang kaya raya, tidak boleh mempunyai sifat sombong, dan menganggap orang lain rendah. Sebab tinggi rendahnya derajat seseorang tidak dapat diukur dari status kebangsawanan dan banyak hartanya.

Orang tua Raden Gayung beranggapan bahwa Raden Sukat tidak pantas membina rumah tangga dengan Raden Gayung. Ia berasal dari keluarga miskin dan bukan dari golongan bangsawan. Maka dianggap tidak sederajat dan tidak seadat. Atas kesombongannya selain membuat keluarga Raden Sukat menjadi kecewa dan tersinggung harga dirinya, juga ia menjadi bingung sendiri lantaran anaknya sakit memikirkan Raden Sukat. Peristiwa sakitnya Raden
Gayung, membuat orang tuanya berubah pikiran, dan menyadari bahwa mereka merasa bersalah dalam bertindak. Oleh karena itu, ia sadar bahwa cinta itu masalah hati, bukan masalah status dan harta. Hal ini kemudian diungkapan dalam cerita ini bahwa sebenarnya cinta sejati antara Raden Sukat dan Raden Gayung tidak mudah dirobohkan. Ayah Raden Gayung baru menyadari bahwa sebenarnya cinta sejati itu tidak dapat dipisahkan, sampai kapan pun dan dimana pun cinta sejati itu akan tetap tumbuh dan berkobar serta abadi. Demikian halnya dengan cinta sejati antara Raden Sukat dan Raden Gayung. Cintanya Raden Gayung kepada Raden Sukat ternyata tidak dapat di ukur dengan sesuatu apapun, walau orang tua berusaha menghiburnya dan menjodohkan kepada laki-laki lain yang lebih tampan dan kaya, Raden Gayung tetap saja menolaknya. Ia tetap setia pada cintanya. Kesetiaan cintanya ia pertahankan, demi terwujudnya citacita dalam membina rumah tangga dengan Raden Sukat.

Nilai Budaya yang terdapat dalam cerita ini adalah nilai kesabaran, keuletan, ketekunan, dan kejujuran. Kesabaran, keuletan, ketekunan Akhmad dalam melakukan suatu pekerjaan merupakan hal yang tidak mudah dan memerlukan suatu pengorbanan. Tapi apabila pekerjaaan dilakukan dengan sepenuh hati, ikhlas dan tanggungjawab tentu akan berhasil. Nilai-nilai inilah yang dimiliki oleh Akhmad. Ia ikhlas melakukan apa saja sebab ia sadar dan bertanggungjawab atas segala kesalahannya. Ia pun sadar, Allah SWT tidak akan memaafkan apabila Pak Tua pemilik buah apel itu 
tidak memberi maaf kepadanya. Karena keuletan, dan kesabaran itulah Akhmad pantas mendapatkan anak gadis Pak Tua yang berparas cantik. Hal yang sudah sewajarnya, dan menjadi peribahasa berakit-rakit ke hulu, berenang-renang ketepian. Bersakitsakit dahulu bersenang-senang kemudian. Aplikasinya, berjuang dahulu atau bekerja keras dahulu di akhir tentu meraih keberhasilan dan kesenangan.

Demikian halnya kejujuran. Dalam agama, manusia dianjurkan agar berlaku jujur. Dalam ajaran agama apapun dikatakan bahwa orang harus hidup dengan kejujuran. Kejujuran merupakan modal utama dalam kehidupan, karena dengan bermodal kejujuran orang akan menimbulkan rasa simpati dan percaya sepenuh hati. Andai kata seseorang sekali berbuat tidak jujur (berbohong) atau curang, selamanya orang tidak akan percaya lagi, hilang kepercayaan, dan tumbuh kembali rasa percaya kembali tidaklah mudah, tetapi membutuhkan waktu dan proses.

Untuk memiliki rasa kejujuran pada seorang anak perlu binaan keluarga. Anak yang baik akan turut pada perintah orang tua. Ia tidak pernah berbuat bohong, curang, sombong, dengki. Apa diamanatkan selalu dilaksanakan. Prilaku demikian dimiliki oleh Abdullah. Ia jujur, bermurah hati, patuh kepada perintah orang tua.

Orang jujur umumnya selalu disenangi, tapi ada pula bila orang berkata jujur seperti yang menyayangi. Sang perampok, misalnya merasa heran masih ada orang yang jujur, seperti Abdullah.
Dengan berkata jujur, Abdullah selamat dan perampok pun bertobat. Abdullah, berhasil mengetuk hati nurani si perampok, sehingga menyadari kesalahannya. Semua itu sebenarnya untuk mengingatkan pada manusia agar selalu berbuat kejujuran. Manusia yang ingat akan Tuhan dan tetap melakukan kebaikan, orang itu beruntung dan bahagia. Oleh karena itu tetaplah berpegang pada kebenaran dan kejujuran dalam keadaan iman seperti apapun. Sebab hal itu merupakan perintah Allah SWT. Allah SWT. yang akan memberi rahmat. Kejujuran merupakan salah satu nilai budaya yang perlu dikembangkan dan dilestarikan.

Nilai budaya yang terdapat pada cerita Betung Bengawan, antara lain yang berkenaaan nilai didaktik (pendidikan dan pengajaran), dan nilai etik. Nilai didaktik, misalnya pendidikan dan ajaran-ajaran budi pekerti. Nilai Etik, misalnya tentang kesetiaan, ketaatan, kejujuran, keberanian, keuletan, ketulusan, dan ketabahan. Dalam cerita ini unsur pendidikan tentang ketabahan, ketulusan dan keberanian tercermin pada sifat yang dimiliki oleh Pangiran Sangun. Ia tulus, taat dan berani melakukan apa saja yang diperintahkan oleh keenam kakaknya. Ia tidak menyangka kakak-kakaknya akan membinasakan dirinya. Atas ketabahan dan ketulusan Pangiran Sangun, kiranya Tuhan pun tidak merestui perbuatan kakak-kakaknya, maka apa yang direncanakan mereka selalu gagal. Walaupun Pangiran Sangun telah mengetahui keenam kakak-kakaknya memiliki itikad tidak baik, tetapi dalam pikirannya tidak terlintas ingin membalasnya. Apa yang dimiliki atas kelebihan pada dirinya pun, Pangiran 
Sangun tetap tidak berlaku sombong. Ia sadar bila berlaku sombong, tentu akan mencelakakan dirinya. Ajaran yang mengandung ajakan-ajakan dan nasihat-nasihat yang mengingatkan kepada kita, antara lain janganlah terlalu fanatik terhadap adat seandainya akan merenggangkan persaudaraan, bahkan akan mendatangkan perselisihan. Hindari tindakan yang tidak terpuji, apalagi yang akan merugikan orang lain. Berilah kesempatan kepada orang lain untuk meminta maaf atas kekhilapannya.

Seorang raja sebagai pemangku adat, hendaknya bertindak hati-hati, jangan justru menjadi pemicu permusuhan. Dalam kisah ini adalah Raja Senapik yang seharusnya memberikan perlindungan dan pembinaan bagi warganya, apalagi pada anak-anaknya. Ia harusnya dapat meredam perselisihan ini dan memberi solusi, agar mereka rukun kembali. Dalam pelestarian adat, antara lain kebiasaan pemberian gelar kebangsawanan kepada setiap anak yang akan dikhitan, adat pemberian gelar itu dapat dipertahankan sepanjang tidak mendatangkan perselisihan. Perihal ketetapan siapa sebenarnya yang berhak memberi gelar kebangsawanan tersebut, tentu tidak boleh dilakukan oleh sembarang orang, apalagi gelar sendiri hasil pemberian sendiri pula.

\section{Nilai Sosial}

Nilai sosial erat kaitannya dengan nilai budaya maupun nilai religius. Ketiga nilai ini satu dengan yang lainnya tidak dapat dipisahpisahkan, sebab merupakan satu kesatuan yang utuh dalam kebutuhan kehidupan manusia. Dalam tingkat abstraksinya nilai sosial akan tampak nyata dibanding nilai budaya. Kalau nilai budaya merupakan gagasangagasan dan pola ideal masyarakat tentang segala sesuatu yang dipandang baik dan berguna, maka pada nilai-nilai sosial gagasan itu telah dituangkan dalam bentuk norma-norma, aturanaturan, dan hukum. Nilai sosial inilah yang menjadi pedoman langsung bagi setiap tingkah laku manusia sebagai anggota suatu masyarakat, yang di dalamnya memuat sanksi-sanksi bagi siapa saja yang melanggarnya.

Nilai sosial terungkap dalam cerita ini ketika orang tua Raden Gayung mulai menyadari tinggi rendahnya derajat manusia tidak dapat diukur oleh faktor status (kebangsawanan) dan jumlah kekayaannya. Di mata Allah Swt. manusia itu dipandang sama, dan yang membedakannya hanyalah tingkat ketaqwaannya. Pernikahan Raden Sukat dan Raden Gayung disetujui oleh kedua orang tua mempelai istri itu merupakan gambaran, bahwa pandangan itu keliru karena sudah tidak sesuai lagi dengan keadaan jaman. Penilaian baik atau buruknya seseorang bergantung pada perilaku dan amal perbuatannya.

Nilai Sosial yang dimaksud dalam cerita ini, adalah mengenai etika dalam kehidupan keluarga. Seperti kita ketahui keluarga adalah kelompok sosial terkecil yang menjadi dasar dan sumber terbentuknya kelompok sosial yang lebih besar, yaitu masyarakat. Di dalam keluarga inilah berlangsungnya proses enkulturasi atau pembinaan nilai-nilai budaya pada seseorang individu yang menjadi bekal untuk 
memasuki kehidupan yang lebih luas dalam masyarakat.

Setiap kebudayaan memberikan batas-batas yang tegas pada setiap unsur pokok yang membentuk rumah tangga, yakni suami dan istri, tentang kedudukan dan peranannya, serta hak dan kewajibannya yang pada dasarnya mempertegas kembali kodrat mereka dalam visi budayanya. Dalam cerita ini, Akhmad sebagai kepala keluarga dengan tekun mengangkat tata nilai Islam sebagai visi budaya yang melatar-belakangi terbentuknya nilainilai dan norma-norma dalam kehidupan keluarga. Hal ini dapat dilihat dari kebiasaan dalam keseharian rajin dan tekun beribadat kepada Tuhan. Selain mengerjakan kewajiban sembahyang yang lima waktu, ia pun sering berzikir di tengah malam dan mengerjakan sholat sunat lainnya. Ketaatan ini ia terapkan kepada istri dan anaknya. Pokok-pokok ajaran mengenai kewajiban antara suami, istri dan anak ia ajarkan.

Akhmad sebagai suami, mempunyai kewajiban untuk membina dan meningkatkan kualitas ketaqwaan pada anggota keluarganya kepada Tuhan Yang Mahaesa. Suami dan istri sebagai dua pribadi yang telah meningkatkan diri dalam satu kesatuan (rumah tangga) dibebani pula dengan hak-hak dan kewajiban sesuai dengan kedudukannya di dalam keluarga. Suami dalam kedudukannya sebagai pemimpin berkewajiban membimbing dan mengajari istrinya dengan ilmu fiqih (Syari'at Islam), menafkahi, dan memberikan perlindungan. Sedangkan istri dalam kedudukannya sebagai yang dipimpin mempunyai kewajiban untuk mengabdikan dirinya dengan sepenuh hati dan menjaga kehormatan diri dan suaminya. Adapun hak-hak suami dan istri adalah kebalikan dari kewajibankewajibannya. Artinya, apa yang menjadi hak suami adalah kewajiban Istrinya. Sebaliknya, apa yang merupakan kewajiban suaminya, adalah hak bagi istrinya.

Dalam cerita ini, nasib berkata lain. Dalam usia tidak terlalu tua Akhmad telah meninggal dunia, dipanggil oleh Allah SWT. Anak lakilakinya yang baru usia dua tahun pun harus diasuh dan dibina oleh ibu dan kakeknya. Namun, itu tidak menjadi rintangan karena Akhmad sebelumnya tentu telah menanamkan nilai ajaran Islam kepada istrinya. Dengan berbekal itu istrinya dapat membina anaknya dengan nilai-nilai Islam.

Kewajiban orang tua, mendidik anaknya agar menjadi orang yang berguna bagi keluarga, masyarakat, nusa, bangsa dan agama. Kewajiban anak menghargai, menghormati, dan mematuhi segala nasihat orang tua. Demikian halnya dengan Abdullah, mematuhi nasihat ibunya sewaktu akan berangkat mengembara. Ibunya berpesan agar ia selalu berbuat baik.

Menuntut ilmu merupakan kewajiban semua orang, tidak memandang usia maupun kaya atau miskin. Orang tua wajib memberi dorongan agar apa yang dicita-citakan oleh anaknya berhasil sesuai dengan yang diharapkan. Demikain halnya dengan Abdullah, ibunya sangat mendukung cita-citanya. Sebagai rasa kasih sayang kepada anaknya, seorang ibu selalu menasihati dan memperingatkan supaya anaknya kelak hidupnya selamat, mendapat berkah dari Tuhan Yang Mahaesa serta berguna bagi nusa bangsa, dan agama. 
Cerita yang mengisahkan perjalanan hidup seseorang, yakni bernama Pangiran Sangun. Dia berasal dari golongan masyarakat biasa, diangkat anak oleh sebuah keluarga golongan bangsawan, yaitu keluarga Raja Senapik. Pangiran Sangun selama tinggal di keluarga itu mendapat tantangan dan rintangan dari keenam saudara anak laki-lakinya. Mereka menaruh rasa dendam kepadanya lantaran ada kesalahpahaman dalam pemaknaan tradisi pemberian nama gelar. Mereka berusaha membinasakan Pangiran Sangun. Namun ia tetap ikhlas, tekun dan berani mengahadapi tantangan mereka. Dalam menghadapi hal tersebut dia selalu berlindung kepada Yang Mahakuasa.

Cerita ini dapat dijadikan cermin bagi kita atau memberikan petunjuk dan tuntunan bagaimana seseorang harus bersikap, berperilaku, dan bertindak dalam kehidupan keluarga dan bermasyarakat. Dalam hidup berkeluarga, ayah sebagai kepala keluarga berkewajiban membina anggota keluarganya Raja Senapik, sebagai seorang raja dan sekaligus kepala keluarga (seorang bangsawan) seyogyanya mampu pembina anakanaknya, agar mereka hidup rukun, saling menghargai, tanpa harus membeda-bedakan status masyarakat. Peran orang tua sangat diperlukan dalam pembentukan karakter dan perilaku anak-anaknya. Orang yang berperilaku buruk akan memperoleh keburukan, dan sebaliknya orang yang berperilaku baik kelak akan memetik kebaikan. Kerja keras, tekun, dan berani menghadapi segala tantangan maupun rintangan dalam kehidupan adalah kunci keberhasilan dalam untuk meraih sesuatu cita-cita. Keberanian dalam mempertahankan kebenaran merupakan tugas mulia yang harus tetap dijunjung tinggi, karena Yang Mahakuasa akan selalu melindungi. Bersikap mengalah untuk menang, adalah sikap yang tepat untuk menghadapi sausana yang emosional. Sikap dan prilaku demikian selayaknya harus dimiliki oleh seorang pemimpin masyarakat, seperti halnya perilaku Pangiran Sangun Ratu Kabuyutan.

\section{PENUTUP}

Cerita rakyat masyarakat Lampung sarat dengan nilai-nilai luhur budaya bangsa yang masih relevan dengan kehidupan masa kini. Adapun nilai luhur tersebut, antara lain nilai religius, nilai budaya dan nilai sosial.

Yang tersirat dalam nilai religius, di antara lain berkeyakinan bahwa di luar kehidupan manusia masih ada kehidupan lainnya, dan terdapat kekuatan lainnya yang sangat mempengaruhi kehidupan manusia. Orang Lampung meyakini anak adalah amanah atau titipan dari Tuhan. Oleh karena itu orang tua berkewajiban menjaga, memelihara, mendidik serta pembina anak-anaknya dengan baik agar kelak anak tersebut menjadi anak yang shaleh dan bertakwa kepada Tuhan Yang Mahaesa.

Dalam nilai budaya, mereka meyakini bahwa manusia hidup tidak dapat melepaskan diri dari aturanaturan, dan norma-norma yang telah disepakati sebagai pedoman dan pandangan hidup. Untuk mewujudkan agar seorang anak menjadi "orang", orang Lampung sejak dini sudah mulai menanamkan niliai-nilai luhur yang bersumber dari ajaran agama, adat 
istiadat dan tradisi serta norma-norma sosial yang ada di dalam masyarakat yang digali dari isi dan makna sastra lisan (cerita rakyat). Terkait dengan nilai sosial, mereka berpandangan pula bahwa bila aturan-aturan dan normanorma yang dipegang sebagai pedoman hidup tetap dipertahankan oleh setiap individu tentu ia akan memberi manfaat bagi keluarga dan yang menyadari akan pentingnya hidup bermasyarakat.

Oleh karena itu, cerita-cerita tersebut patut dipertahankan dan perlu diformulasikan ke masyarakat pendukungnya, khususnya kepada generasi muda agar mereka lebih mengenal identitas dirinya. Dengan menjunjung nilai-nilai budaya sebagai warisan leluhurnya, maka akan tumbuh jati diri sebagai pembetukan karater bangsa.

\section{DAFTAR PUSTAKA}

Ahmad Yunus, Rosyadi, Tatik Kartikasari I Made Purna Ambo Gani, 1997/1998.

\section{Kajian Analisis Hikayat}

Budistihara. Jakarta: Depdikbud.

Andre Harjana.1981.

Kritik Sastra Sebuah Pengantar . Jakarta: Gramedia.

Anton Mulyono, Sri Sukesi Adiwimarta, Adi Sunaryo, Hermanoe, Sri Timur Suratman,Umi Basiroh.1990. Kamus Besar Bahasa Indonesia. Jakarta: Balai Pustaka.

Beals, Ralph, L. 1956.

An Introduction to Anthropology. New York: The Macmilan Company.

Danandjaja, James. 1984.
Foklor Indonesia, Ilmu Gosif,

Dongeng, dan lain-lain. Jakarta:

Grafiti, Press.

1990.

Kegunaan Cerita Rakyat, Sawerigading sebagai Sumber Sejarah Lokal Daerah-daerah di Sulawesi. Jakarta: Depdikbud.

Darmono, Sapardi Djoko. 1979.
Sosiologi Sastra Sebuah
Pengantar. Jakarta: Pusat
Pembinaan dan Pengembangan
Bahasa.

Koentjaraningrat. 1982.

Kebudayaan Mentalitas dan

Pembangunan. Jakarta:

Gramedia.

Kebudayaan Nasional Indonesia, Fungsi Kebudayaan Nasional Indonesia. Jakarta: Kompas, Senin, 9 Maret, Bagian Pertama dari Empat Tulisan

Mangunwijaya, J.B. 1982.

Sastra dan Religiusitas. Jakarta: Sinar Harapan.

Matulada, (Ed).1990.

Sawerigading,

Folktale

Sulawesi. Jakarta: Depdikbud.

Panuti Sudjiman. 1996.

Nusa Jawa: Silang Budaya Kajian Sejarah Terpadu Bagian III, Warisan Kerajaan-Kerajaan Konsentris. Jakarta: Gramedia. 1984.

Kamus Istilah Sastra. Jakarta: Gramedia.

Pigeaud, Th. G. Th. 1967.

Literature of Java Volume I: of Javanese Literature 900-1900 AD, Martinus Nijhaff, The Hague. 
Poerwadarminta, WJS. 1985.

Kamus Besar Bahasa Indonesia. Jakarta: Balai Pustaka.

Warnidah Achyar, Husin Sayuti, Adela Hasyim, Amizan Wardi, 1985/1986. Struktur Sastra Lisan Lampung. Jakarta: Pusat Pembinaan dan Pengembangan Bahasa.
Yetty Kusmiyati Hadish.1979.

Sastra Lisan Sunda, Mite Fabel, dan Legenda. Jakarta: Pusat Pembinaan dan Pengembangan Bahasa, Depdikbud. 